\title{
Triggering of Suicidal Erythrocyte Death by Zosuquidar
}

\author{
Marilena Briglia ${ }^{a, b} \quad$ Antonella Fazio ${ }^{a, b} \quad$ Caterina Faggio ${ }^{b} \quad$ Florian Lang $^{a}$ \\ aDepartment of Physiology, University of Tübingen, Germany; 'bepartment of Chemical, Biological, \\ Pharmaceutical and Environmental Sciences-University of Messina Viale Ferdinando Stagno \\ d'Alcontres, S. Agata-Messina, Italy
}

\section{Key Words}

Phosphatidylserine • Calcium • Cell volume • SB203580 • Calphostin • Eryptosis

\begin{abstract}
Background: The P-glycoprotein inhibitor zosuquidar (LY335979) is clinically used to augment the effect of cytostatic drugs on suicidal tumor cell death or apoptosis. The present study explored whether the substance is cytotoxic to erythrocytes. Upon injury, erythrocytes may undergo suicidal cell death or eryptosis, which is characterized by cell shrinkage and translocation of cell membrane phosphatidylserine to the erythrocyte surface. Signaling of eryptosis include increase of cytosolic $\mathrm{Ca}^{2+}$-activity $\left(\left[\mathrm{Ca}^{2+}\right]_{i}\right)$, oxidative stress and activation of several kinases, such as p38 kinase and protein kinase C. Methods: Phosphatidylserine abundance at the erythrocyte surface was quantified from binding of FITC-labelled annexin-V, cell volume from forward scatter, $\left[\mathrm{Ca}^{2+}\right]_{\mathrm{i}}$ from Fluo3-fluorescence, and reactive oxygen species (ROS) from 2',7'-dichlorodihydrofluorescein diacetate (DCFDA) fluorescence. Results: A 48 $\mathrm{h}$ treatment of human erythrocytes with zosuquidar significantly increased the percentage of annexin-V-binding cells ( 2 and $4 \mu \mathrm{g} / \mathrm{ml})$, significantly decreased forward scatter $(4 \mu \mathrm{g} /$ $\mathrm{ml})$, significantly increased $\left[\mathrm{Ca}^{2+}\right]_{\mathrm{i}}(4 \mu \mathrm{g} / \mathrm{ml})$, but did not significantly modify ROS. The upregulation of annexin-V-binding following zosuquidar $(4 \mu \mathrm{g} / \mathrm{ml})$ treatment was significantly blunted by removal of extracellular $\mathrm{Ca}^{2+}$, by presence of p38 kinase inhibitor SB203580 $(2 \mu \mathrm{M})$ and by presence of protein kinase $C$ inhibitor calphostin $(100 \mathrm{nM})$. Conclusions: Exposure of erythrocytes to zosuquidar triggers suicidal erythrocyte death with erythrocyte shrinkage and erythrocyte membrane scrambling, an effect involving $\mathrm{Ca}^{2+}$ entry and requiring activity of SB203580 and calphostin sensitive kinases.

M. Briglia and A. Fazio contributed equally and thus share first authorship.

Prof. Dr. Florian Lang

KARGER 125
Physiologisches Institut der Universität Tübingen, Gmelinstr. 5, D-72076 Tübingen (Germany) Tel. +49 707129 72194, Fax +49 707129 5618, E-Mail florian.lang@uni-tuebingen.de 


\section{Introduction}

Zosuquidar (LY335979), a highly specific P-glycoprotein (multi drug resistance) inhibitor [1-11], has been used in the treatment of malignancy [2, 5, 9, 12-26] and interferes with drug efflux at the blood brain barrier [1, 27-29]. Moreover, zosuquidar or its derivatives may be effective on selected bacterial and fungal ABC transporters [30]. The inhibitory effect of zosuquidar on P-glycoprotein impairs the efflux of cytotoxic drugs thus fostering apoptosis of treated cells [30-32].

Similar to apoptosis of nucleated cells erythrocytes may enter suicidal cell death or eryptosis, which is characterized by cell shrinkage [33] and cell membrane scrambling with translocation of phosphatidylserine to the erythrocyte surface [34]. Signaling involved in the stimulation of eryptosis include $\mathrm{Ca}^{2+}$ entry with increase of cytosolic $\mathrm{Ca}^{2+}$ activity $\left(\left[\mathrm{Ca}^{2+}\right]_{\mathrm{i}}\right)$, ceramide [35], oxidative stress [34], caspase activation [34, 36, 37], enhanced activity of casein kinase $1 \alpha$, Janus-activated kinase JAK3, protein kinase $\mathrm{C}$, or p38 kinase, as well as impaired activity of AMP activated kinase AMPK, cGMP-dependent protein kinase, PAK2 kinase [34] or sorafenib \& sunitinib sensitive kinases [34]. Due to triggering of the respective signaling eryptosis is stimulated by a myriad of xenobiotics [34, 38-73].

The present study explored, whether zosuquidar stimulates eryptosis. To this end, erythrocytes from healthy volunteers were exposed for 48 hours to zosuquidar, and phosphatidylserine abundance at the erythrocyte surface estimated using annexin-Vbinding, cell volume from forward scatter, $\left[\mathrm{Ca}^{2+}\right]_{\mathrm{i}}$ from Fluo3-fluorescence, and abundance of reactive oxygen species (ROS) from $2^{\prime}, 7^{\prime}$-dichlorodihydrofluorescein diacetate (DCFDA) fluorescence. The involvement of kinases was tested utilizing p38 kinase inhibitor SB203580 and protein kinase $\mathrm{C}$ inhibitor calphostin.

\section{Materials and Methods}

\section{Erythrocytes, solutions and chemicals}

Fresh Lithium-Heparin-anticoagulated blood samples were kindly provided by the blood bank of the University of Tübingen. The study is approved by the ethics committee of the University of Tübingen (184/2003 V). The blood was centrifuged at $120 \mathrm{~g}$ for $20 \mathrm{~min}$ at $23^{\circ} \mathrm{C}$ and the platelets and leukocytes-containing supernatant was disposed. Erythrocytes were incubated in vitro for 48 hours at a hematocrit of $0.4 \%$ in Ringer solution containing (in mM) $125 \mathrm{NaCl}, 5 \mathrm{KCl}, 1 \mathrm{MgSO}_{4}, 32 \mathrm{~N}$-2-hydroxyethylpiperazine-N-2-ethanesulfonic acid (HEPES), 5 glucose, and $1 \mathrm{CaCl}_{2}$; the $\mathrm{pH}$ was adjusted to 7.4 and the temperature kept at $37^{\circ} \mathrm{C}$. Where indicated, erythrocytes were exposed to zosuquidar (Sigma Aldrich, Hamburg, Germany, stock solution: $4 \mathrm{mg} /$ $\mathrm{ml}$ in water) in the absence or presence of p38 kinase inhibitor SB203580 (Enzo Life Sciences, Farmingdale, USA, stock solution: 20 mM in DMSO ) or calphostin (Cayman, Ann Arbor, USA, stock solution:1 mM in DMSO).

\section{Annexin-V-binding and forward scatter}

After incubation under the respective experimental condition, a $100 \mu \mathrm{l}$ cell suspension was washed in Ringer solution containing $5 \mathrm{mM} \mathrm{CaCl}_{2}$ and then stained with Annexin-V-FITC (1:200 dilution; ImmunoTools, Friesoythe, Germany) in this solution at $37^{\circ} \mathrm{C}$ for 20 min under protection from light. In the following, the forward scatter (FSC) of the cells was determined and annexin-V- FITC fluorescence intensity was measured with an excitation wavelength of $488 \mathrm{~nm}$ and an emission wavelength of $530 \mathrm{~nm}$ on a FACS Calibur (BD, Heidelberg, Germany). In some experiments erythrocytes were preincubated in $\mathrm{Ca}^{2+}$ free solution. For determination of annexin-V-binding, addition of $\mathrm{Ca}^{2+}\left(5 \mathrm{mM} \mathrm{CaCl}_{2}\right)$ was required during the $15 \mathrm{~min}$ incubation with FITC-annexin V. Immediately thereafter measurements were done so that the exposure to $\mathrm{Ca}^{2+}$ was too short to trigger significant phosphatidylserine translocation.

Intracellular $\mathrm{Ca}^{2+}$

After incubation, a $100 \mu \mathrm{l}$ cell suspension was washed in Ringer solution and then loaded with Fluo-3/ AM (Biotium, Hayward, USA) in Ringer solution containing $5 \mu \mathrm{M}$ Fluo-3/AM. The cells were incubated at $37^{\circ} \mathrm{C}$ for $30 \mathrm{~min}$ and washed twice in Ringer solution. The Fluo-3/AM-loaded erythrocytes were resuspended in 
$200 \mu \mathrm{l}$ Ringer. Then, $\mathrm{Ca}^{2+}$-dependent fluorescence intensity was measured with an excitation wavelength of $488 \mathrm{~nm}$ and an emission wavelength of $530 \mathrm{~nm}$ on a FACS Calibur.

Reactive oxygen species (ROS)

Oxidative stress was determined utilizing 2',7'-dichlorodihydrofluorescein diacetate (DCFDA). After incubation, a $100 \mu \mathrm{l}$ suspension of erythrocytes was washed in Ringer solution and then stained with DCFDA (Sigma, Schnelldorf, Germany) in Ringer solution containing DCFDA at a final concentration of 10 $\mu \mathrm{M}$. Erythrocytes were incubated at $37^{\circ} \mathrm{C}$ for $30 \mathrm{~min}$ in the dark and then washed three times in Ringer solution. The DCFDA-loaded erythrocytes were resuspended in $200 \mu$ Ringer solution, and ROS-dependent fluorescence intensity was measured at an excitation wavelength of $488 \mathrm{~nm}$ and an emission wavelength of $530 \mathrm{~nm}$ on a FACS Calibur (BD).

\section{Statistics}

Data are expressed as arithmetic means \pm SEM. As indicated in the figure legends, statistical analysis was made using ANOVA with Tukey's test as post-test and $t$ test as appropriate. $\mathrm{n}$ denotes the number of different erythrocyte specimens studied. Since different erythrocyte specimens used in distinct experiments are differently susceptible to triggers of eryptosis, the same erythrocyte specimens have been used for control and experimental conditions.

\section{Results}

The present study explored whether zosuquidar stimulates eryptosis, the suicidal death of erythrocytes characterized by cell membrane scrambling with phosphatidylserine translocation to the cell surface and by cell shrinkage.

The phosphatidylserine abundance at the cell surface was quantified by determination of FITC-labelled annexin-V, which tightly binds to phosphatidylserine. FITC-labelled annexin- $V$ was determined by flow cytometry. As shown in Fig. 1, a 48 hours exposure to zosuquidar increased the percentage of annexin-V-binding erythrocytes, an effect reaching statistical significance at $2 \mu \mathrm{g} / \mathrm{ml}$ zosuquidar concentration.

Erythrocyte cell volume was estimated from forward scatter determined in flow cytometry. As illustrated in Fig. 2, a 48 hours exposure to zosuquidar was followed by a

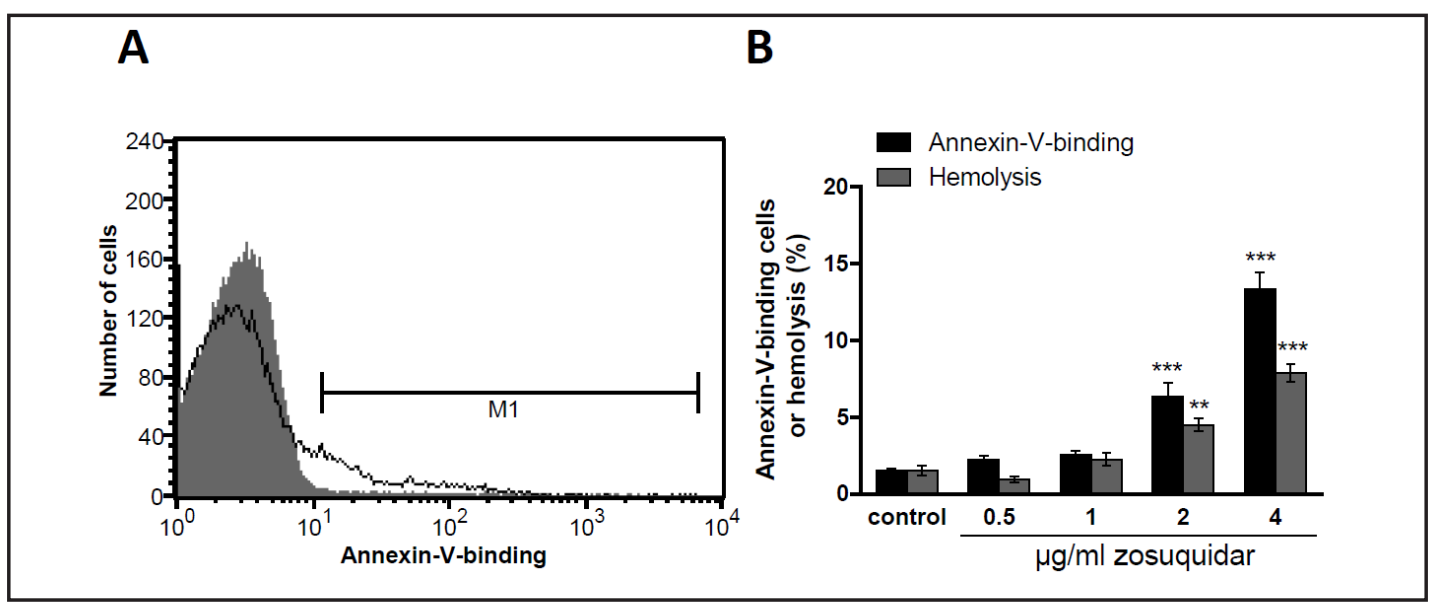

Fig. 1. Effect of zosuquidar on phosphatidylserine exposure. A. Original histogram of annexin-V-binding of erythrocytes following exposure for $48 \mathrm{~h}$ to Ringer solution without (grey area) and with (black line) presence of $4 \mu \mathrm{g} / \mathrm{ml}$ zosuquidar. M1 indicates the annexin-V-fluorescence defining the percentage of annexin-Vbinding erythrocytes. B. Arithmetic means \pm SEM of erythrocyte annexin-V-binding $(n=7)$ following incubation for $48 \mathrm{~h}$ to Ringer solution without (white bar) or with (black bars) presence of zosuquidar (0.5 - $4 \mu \mathrm{g}$ / $\mathrm{ml})$. For comparison, the effect of zosuquidar on hemolysis is shown (grey bars). ${ }^{* *}(\mathrm{p}<0.01),{ }^{* * *}(P<0.001)$ indicates significant difference from the absence of zosuquidar (ANOVA). 
A

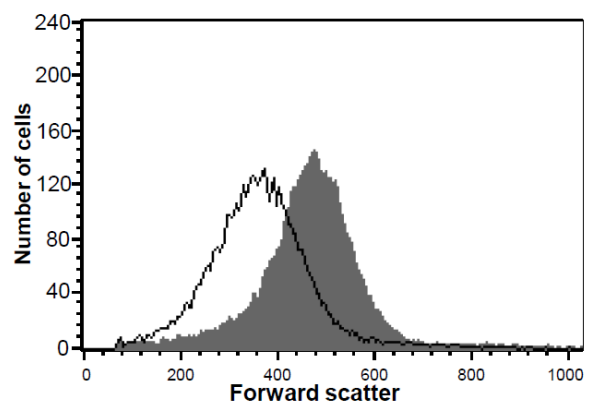

B

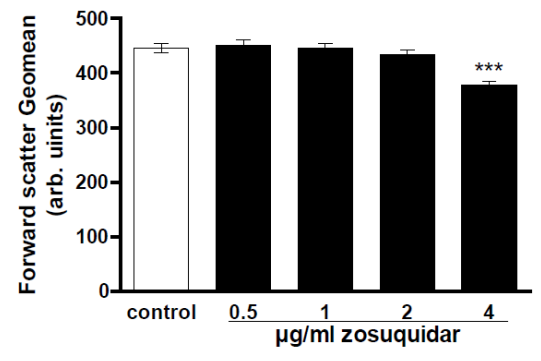

Fig. 2. Effect of zosuquidar on erythrocyte forward scatter. A. Original histogram of forward scatter of erythrocytes following exposure for $48 \mathrm{~h}$ to Ringer solution without (grey area) and with (black line) presence of $4 \mu \mathrm{g} / \mathrm{ml}$ zosuquidar. B. Arithmetic means \pm SEM $(\mathrm{n}=12)$ of the erythrocyte forward scatter (FSC) following incubation for $48 \mathrm{~h}$ to Ringer solution without (white bar) or with (black bars) zosuquidar $(0.5-4 \mu \mathrm{g} / \mathrm{ml})$. $* * *(P<0.001)$ indicates significant difference from the absence of zosuquidar (ANOVA).

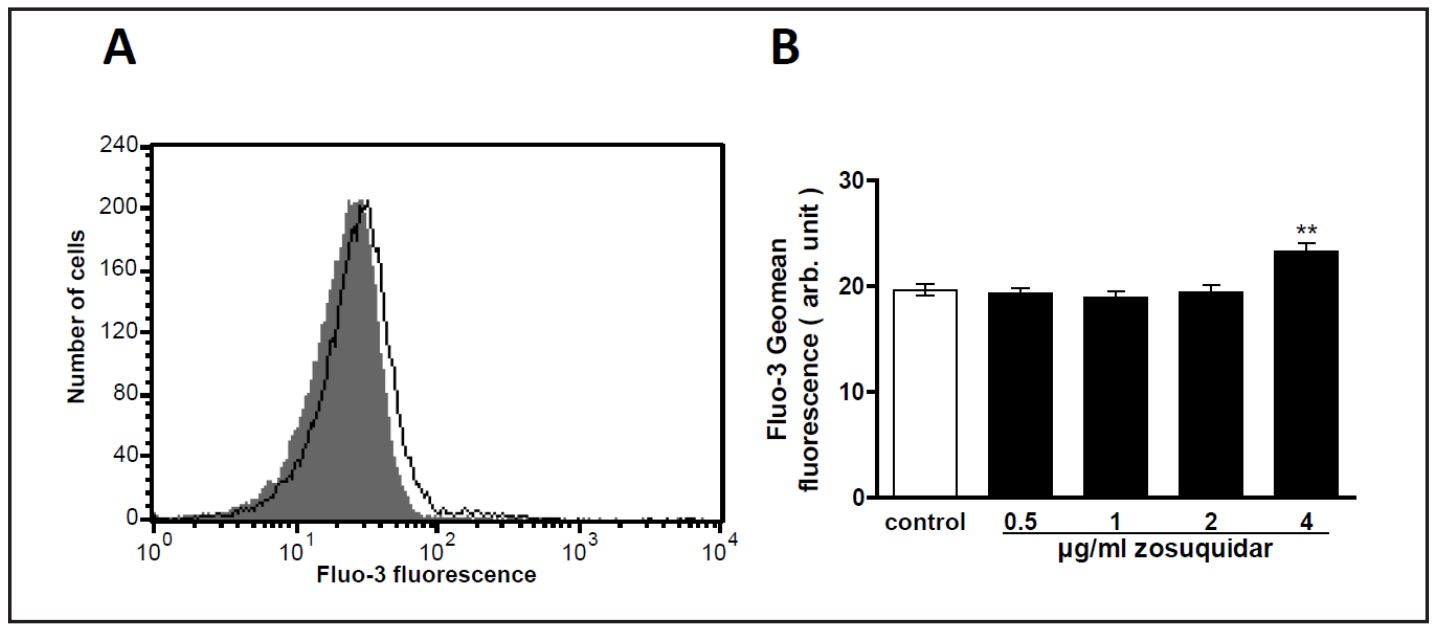

Fig. 3. Effect of zosuquidar on erythrocyte $\mathrm{Ca}^{2+}$ activity. A. Original histogram of Fluo3 fluorescence in erythrocytes following exposure for $48 \mathrm{~h}$ to Ringer solution without (grey area) and with (black line) presence of zosuquidar $(4 \mu \mathrm{g} / \mathrm{ml})$. B. Arithmetic means \pm SEM $(n=5)$ of the Fluo3 fluorescence (arbitrary units) in erythrocytes exposed for $48 \mathrm{~h}$ to Ringer solution without (white bar) or with (black bars) zosuquidar (0.5 $4 \mu \mathrm{g} / \mathrm{ml}) .{ }^{* *}(P<0.01)$ indicates significant difference from the absence of zosuquidar (ANOVA).

decrease of erythrocyte forward scatter, an effect reaching statistical significance at $4 \mu \mathrm{g} / \mathrm{ml}$ zosuquidar concentration.

Both, cell membrane scrambling and cell shrinkage could be triggered by increase of cytosolic $\mathrm{Ca}^{2+}$ activity $\left(\left[\mathrm{Ca}^{2+}\right]_{\mathrm{i}}\right)$. Fluo3 fluorescence was thus employed to explore whether zosuquidar influences cytosolic $\mathrm{Ca}^{2+}$ activity $\left(\left[\mathrm{Ca}^{2+}\right]_{\mathrm{i}}\right)$. As illustrated in Fig. 3, a 48 hours exposure to zosuquidar increased the Fluo3 fluorescence, an effect requiring $4 \mu \mathrm{g} / \mathrm{ml}$ zosuquidar concentration for statistical significance.

In order to test whether zosuquidar-induced translocation of phosphatidylserine to the cell surface required entry of extracellular $\mathrm{Ca}^{2+}$, erythrocytes were incubated for 48 hours in the absence or presence of 2 or $4 \mu \mathrm{g} / \mathrm{ml}$ zosuquidar, both in the presence or nominal absence of extracellular $\mathrm{Ca}^{2+}$. As illustrated in Fig 4, removal of extracellular $\mathrm{Ca}^{2+}$ did not significantly modify the effect of $2 \mu \mathrm{g} / \mathrm{ml}$ zosuquidar, but significantly blunted the effect of $4 \mu \mathrm{g} / \mathrm{ml}$ zosuquidar on annexin-V-binding. Exposure to $2 \mu \mathrm{g} / \mathrm{ml}$ zosuquidar significantly increased the percentage of annexin-V-binding erythrocytes to similarly high levels in the 


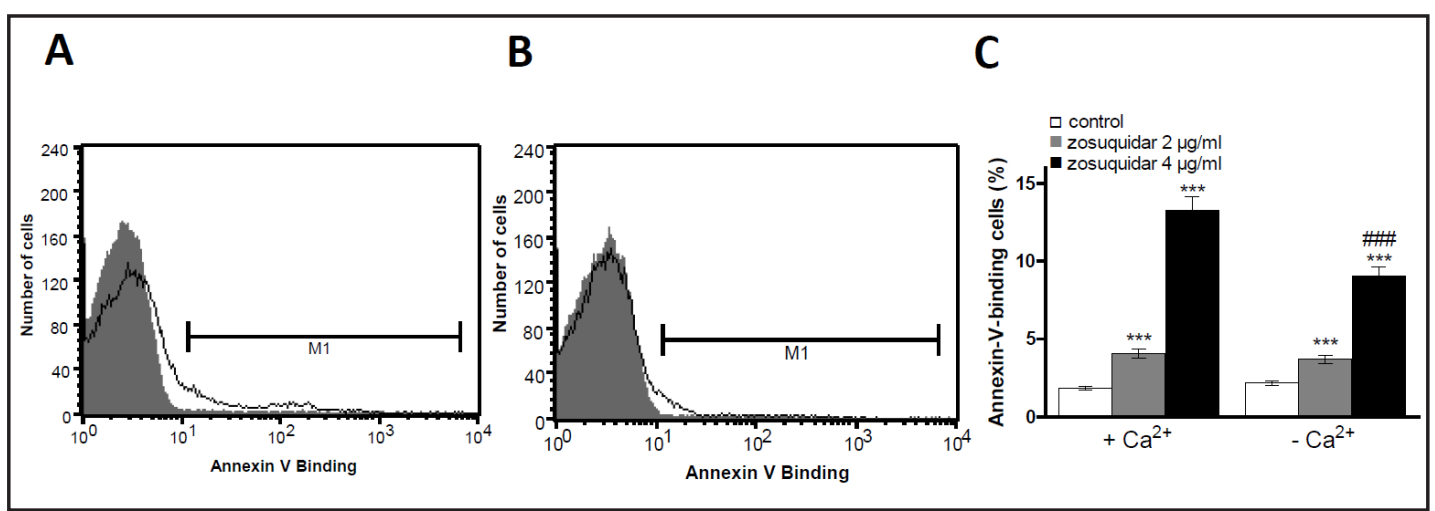

Fig. 4. $\mathrm{Ca}^{2+}$ sensitivity of zosuquidar- induced phosphatidylserine exposure. A,B. Original histograms of annexin-V-binding of erythrocytes following exposure for $48 \mathrm{~h}$ to Ringer solution without (grey areas) and with (black lines) presence of zosuquidar $(4 \mu \mathrm{g} / \mathrm{ml})$ in the presence (A) and absence (B) of extracellular $\mathrm{Ca}^{2+}$. C. Arithmetic means \pm SEM $(\mathrm{n}=12)$ of annexin-V-binding of erythrocytes after a $48 \mathrm{~h}$ treatment with Ringer solution without (white bars) or with $2 \mu \mathrm{g} / \mathrm{ml}$ (grey bars) or $4 \mu \mathrm{g} / \mathrm{ml}$ (black bars) zosuquidar in the presence (left bars, $+\mathrm{Ca}^{2+}$ ) and absence (right bars, $\left.-\mathrm{Ca}^{2+}\right)$ of $\mathrm{Ca}^{2+} . * * *(P<0.001)$ indicates significant difference from the absence of zosuquidar, \#\#\# $(P<0.001)$ indicates significant difference from presence of $\mathrm{Ca}^{2+}$ (ANOVA).

Fig. 5. Effect of zosuquidar on phosphatidylserine exposure in the absence and presence of SB203580 or calphostin. A-C. Original histograms of annexin-V-binding of erythrocytes following exposure for $48 \mathrm{~h}$ to Ringer solution without (grey areas) and with (black lines) presence of zosuquidar (4 $\mu \mathrm{g}$ / $\mathrm{ml}$ ) in the absence of kinase inhibitors (A), in the presence of $2 \mu \mathrm{M}$ SB203580 (B) or in the presence of $100 \mathrm{nM}$ calphostin (C). D. Arithmetic means \pm SEM $(n=13)$ of annexin-V-binding of erythrocytes after a 48 $h$ treatment with Ringer solution without (white

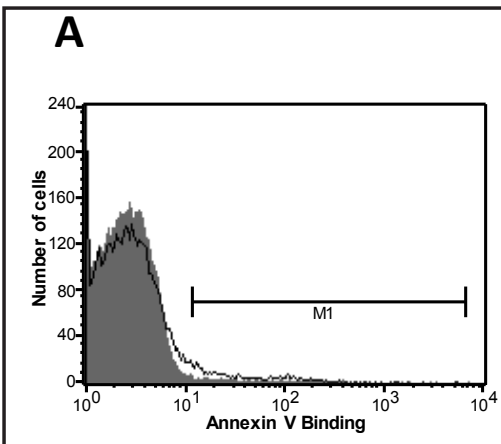

C

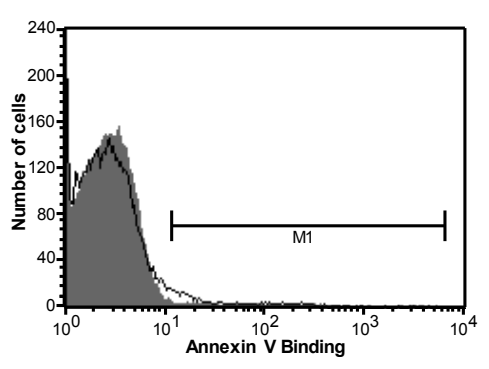

\section{B}

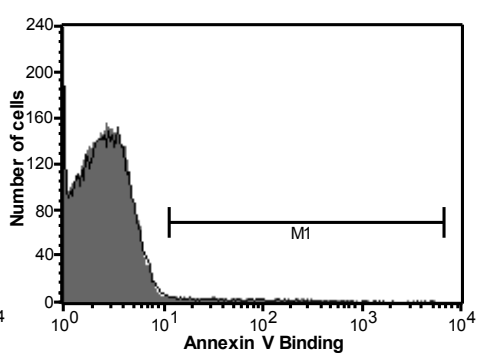

D

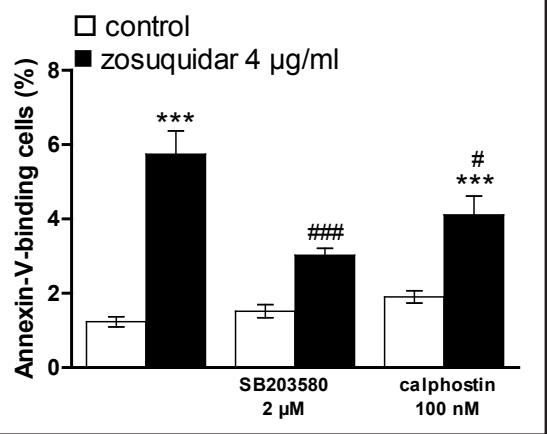

bars) or with (black bars) $4 \mu \mathrm{g} / \mathrm{ml}$ zosuquidar in the absence of kinase inhibitors (left bars) and presence of $2 \mu \mathrm{M}$ SB203580 (middle bars) or of $100 \mathrm{nM}$ calphostin (right bars). ${ }^{* * *}(P<0.001)$ indicates significant difference from the absence of zosuquidar, $\#(p<0.05)$, \#\#\#(P<0.001) indicates significant difference from the respective value in the absence of kinase inhibitors (ANOVA).

absence and in the presence of extracellular $\mathrm{Ca}^{2+}$ and exposure to $4 \mu \mathrm{g} / \mathrm{ml}$ zosuquidar still significantly increased the percentage of annexin-V-binding erythrocytes in the absence of 
extracellular $\mathrm{Ca}^{2+}$. Thus, eryptosis was in large part triggered by mechanisms other than entry of extracellular $\mathrm{Ca}^{2+}$.

Eryptosis could be stimulated by oxidative stress. Thus, 2',7'-dichlorodihydrofluorescein diacetate (DCFDA) fluorescence was utilized to quantify reactive oxygen species (ROS) abundance. As a result, the ROS abundance was similar following a 48 hours incubation in the absence of zosuquidar (17.6 \pm 1.9 a.u., $\mathrm{n}=5)$ and in the presence of $0.5 \mu \mathrm{g} / \mathrm{ml}(14.7 \pm 0.5$ a.u., $\mathrm{n}=5), 1 \mu \mathrm{g} / \mathrm{ml}(15.0 \pm 0.4$ a.u., $\mathrm{n}=5), 2 \mu \mathrm{g} / \mathrm{ml}(15.6 \pm 0.5$ a.u., $\mathrm{n}=5)$ and $4 \mu \mathrm{g} / \mathrm{ml}(17.0$ \pm 0.4 a.u., $\mathrm{n}=5$ ) zosuquidar. Thus, zosuquidar did not appreciably enhance oxidative stress.

In order to test, whether the effect of zosuquidar required kinase activation, the effect of zosuquidar on translocation of phosphatidylserine to the cell surface was determined in the absence and presence of p38 protein kinase inhibitor SB203580 $(2 \mu \mathrm{M})$ or protein kinase C inhibitor calphostin (100 nM). As shown in Fig. 5, addition of either SB203580 or calphostin significantly blunted the effect of zosuquidar on annexin-V-binding.

\section{Discussion}

The present observations uncover a novel effect of zosuquidar, i.e. the stimulation of eryptosis, the suicidal erythrocyte death characterized by erythrocyte shrinkage and erythrocyte cell membrane scrambling with phosphatidylserine translocation from the cell interior to the erythrocyte surface. The zosuquidar concentration required for stimulation of erythrocyte cell membrane scrambling $(2 \mu \mathrm{g} / \mathrm{ml})$ was in the range of the concentrations determined in mice following treatment with $20 \mathrm{mg} / \mathrm{kg}$ zosuquidar [74], but was higher than the concentrations observed in patients $[74,75]$. It must be kept in mind that the susceptibility to eryptosis is enhanced in several clinical conditions, such as malignancy [76], hepatic failure [77], diabetes [78, 79], uremia [44, 80], hemolytic uremic syndrome [81], sepsis [82], fever [83], hyperphosphatemia [69], dehydration [61], mycoplasma infection [84], malaria [85], iron deficiency [86], sickle cell anemia [87], thalassemia [87], glucose-6phosphate dehydrogenase deficiency [87], and Wilson's disease [34,88]. In those conditions, presumably lower concentrations of zosuquidar are required to trigger eryptosis.

Signaling involved in zosuquidar induced eryptosis includes increase of cytosolic $\mathrm{Ca}^{2+}$ activity $\left(\left[\mathrm{Ca}^{2+}\right]_{\mathrm{j}}\right)$, which may contribute to stimulation of cell membrane scrambling by activating an illdefined $\mathrm{Ca}^{2+}$ sensitive scramblase and of cell shrinkage by activation of $\mathrm{Ca}^{2+}$ sensitive $\mathrm{K}^{+}$channels, $\mathrm{K}^{+}$exit, cell membrane hyperpolarization, $\mathrm{Cl}^{-}$exit and thus cellular loss of $\mathrm{KCl}$ with osmotically obliged water [33]. Accordingly, removal of extracellular $\mathrm{Ca}^{2+}$ slightly but significantly blunted the stimulation of annexin-V-binding following treatment with $4 \mu \mathrm{g} / \mathrm{ml}$ zosuquidar. However, removal of extracellular $\mathrm{Ca}^{2+}$ did not appreciably influence the effect of 2 $\mu \mathrm{g} / \mathrm{ml}$ zosuquidar and $4 \mu \mathrm{g} / \mathrm{ml}$ zosuquidar still significantly enhanced the phosphatidylserine abundance at the cell surface in the absence of extracellular $\mathrm{Ca}^{2+}$. Thus, the effect of zosuquidar on $\mathrm{Ca}^{2+}$ entry contributed only little to the stimulation of phosphatidylserine translocation.

Moreover, zosuquidar failed to trigger oxidative stress, a known stimulator of eryptosis [34]. Instead, the effect of zosuquidar on cell membrane scrambling apparently involved activation of kinases. The effect of zosuquidar on cell membrane scrambling was significantly blunted by the p38 kinase inhibitor SB203580 and the protein kinase C inhibitor calphostin.

The stimulation of eryptosis by zosuquidar may lead to anemia, as phosphatidylserine exposing erythrocytes are engulfed by macrophages and thus rapidly cleared from circulating blood [34]. Erythrocytes exposing phosphatidylserine at their surface may further adhere to endothelial cells of the vascular wall [89], stimulate blood clotting and induce thrombosis [90-92]. The stimulation of erythrocyte cell membrane scrambling may thus interfere with microcirculation [35, 90, 93-96].

In conclusion, exposure of human erythrocytes to zosuquidar is followed by stimulation of erythrocyte cell membrane scrambling and cell shrinkage, both hallmarks of eryptosis, the suicidal erythrocyte death. Signaling involved in the effect of zosuquidar on cell membrane scrambling includes $\mathrm{Ca}^{2+}$ entry, p38 kinase and protein kinase $\mathrm{C}$.

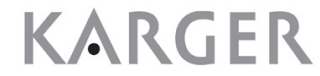




\section{Cellular Physiology Cell Physiol Biochem 2015;37:2355-2365

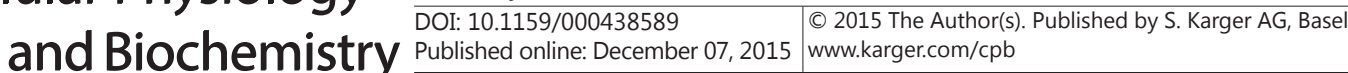 \\ Briglia et al.: Zosuquidar-Induced Eryptosis}

\section{Acknowledgements}

The authors acknowledge the meticulous preparation of the manuscript by Tanja Loch. The study was supported by the Deutsche Forschungsgemeinschaft and Open Access Publishing Fund of Tuebingen University.

\section{Disclosure Statement}

The authors declare no conflict of interest.

\section{References}

1 Anderson BD, May MJ, Jordan S, Song L, Roberts MJ, Leggas M: Dependence of nelfinavir brain uptake on dose and tissue concentrations of the selective P-glycoprotein inhibitor zosuquidar in rats. Drug Metab Dispos 2006;34:653-659.

2 Bates SF, Chen C, Robey R, Kang M, Figg WD, Fojo T: Reversal of multidrug resistance: lessons from clinical oncology. Novartis Found Symp 2002;243:83-96; discussion 96-102, 180-105.

3 Callies S, de Alwis DP, Harris A, Vasey P, Beijnen JH, Schellens JH, Burgess M, Aarons L: A population pharmacokinetic model for paclitaxel in the presence of a novel P-gp modulator, Zosuquidar Trihydrochloride (LY335979). Br J Clin Pharmacol 2003;56:46-56.

4 Callies S, de Alwis DP, Wright JG, Sandler A, Burgess M, Aarons L: A population pharmacokinetic model for doxorubicin and doxorubicinol in the presence of a novel MDR modulator, zosuquidar trihydrochloride (LY335979). Cancer Chemother Pharmacol 2003;51:107-118.

5 Dantzig AH, Law KL, Cao J, Starling JJ: Reversal of multidrug resistance by the P-glycoprotein modulator, LY335979, from the bench to the clinic. Curr Med Chem 2001;8:39-50.

6 Kocharyan A, Feldman R, Singleton A, Han X, Bleier BS: P-glycoprotein inhibition promotes prednisone retention in human sinonasal polyp explants. Int Forum Allergy Rhinol 2014;4:734-738.

7 Lam A, Hoang JD, Singleton A, Han X, Bleier BS: Itraconazole and clarithromycin inhibit P-glycoprotein activity in primary human sinonasal epithelial cells. Int Forum Allergy Rhinol 2015;5:477-480.

8 Paine MF, Leung LY, Watkins PB: New insights into drug absorption: studies with sirolimus. Ther Drug Monit 2004;26:463-467.

9 Ross DD: Modulation of drug resistance transporters as a strategy for treating myelodysplastic syndrome. Best Pract Res Clin Haematol 2004;17:641-651.

10 Thomas H, Coley HM: Overcoming multidrug resistance in cancer: an update on the clinical strategy of inhibiting p-glycoprotein. Cancer Control 2003;10:159-165.

11 Werle M, Takeuchi H, Bernkop-Schnurch A: New-generation efflux pump inhibitors. Expert Rev Clin Pharmacol 2008;1:429-440.

12 Abu Ajaj K, Graeser R, Kratz F: Zosuquidar and an albumin-binding prodrug of zosuquidar reverse multidrug resistance in breast cancer cells of doxorubicin and an albumin-binding prodrug of doxorubicin. Breast Cancer Res Treat 2012;134:117-129.

13 Cnubben NH, Wortelboer HM, van Zanden JJ, Rietjens IM, van Bladeren PJ: Metabolism of ATP-binding cassette drug transporter inhibitors: complicating factor for multidrug resistance. Expert Opin Drug Metab Toxicol 2005;1:219-232.

14 Cripe LD, Uno H, Paietta EM, Litzow MR, Ketterling RP, Bennett JM, Rowe JM, Lazarus HM, Luger S, Tallman MS: Zosuquidar, a novel modulator of P-glycoprotein, does not improve the outcome of older patients with newly diagnosed acute myeloid leukemia: a randomized, placebo-controlled trial of the Eastern Cooperative Oncology Group 3999. Blood 2010;116:4077-4085.

15 Fracasso PM, Goldstein LJ, de Alwis DP, Rader JS, Arquette MA, Goodner SA, Wright LP, Fears CL, Gazak RJ, Andre VA, Burgess MF, Slapak CA, Schellens JH: Phase I study of docetaxel in combination with the P-glycoprotein inhibitor, zosuquidar, in resistant malignancies. Clin Cancer Res 2004;10:7220-7228.

16 Gerrard G, Payne E, Baker RJ, Jones DT, Potter M, Prentice HG, Ethell M, McCullough H, Burgess M, Mehta $\mathrm{AB}$, Ganeshaguru K: Clinical effects and P-glycoprotein inhibition in patients with acute myeloid leukemia treated with zosuquidar trihydrochloride, daunorubicin and cytarabine. Haematologica 2004;89:782-790. 


\section{Cellular Physiology Cell Physiol Biochem 2015;37:2355-2365 \begin{tabular}{l|l|l}
\hline DOI: 10.1159/000438589 & $\begin{array}{l}\text { C } 2015 \text { The Author(s). Published by S. Karger AG, Basel } \\
\text { www.karger.com/cpb }\end{array}$ \\
\hline
\end{tabular} \\ Briglia et al.: Zosuquidar-Induced Eryptosis}

17 Lancet JE, Baer MR, Duran GE, List AF, Fielding R, Marcelletti JF, Multani PS, Sikic BI: A phase I trial of continuous infusion of the multidrug resistance inhibitor zosuquidar with daunorubicin and cytarabine in acute myeloid leukemia. Leuk Res 2009;33:1055-1061.

18 Le LH, Moore MJ, Siu LL, Oza AM, MacLean M, Fisher B, Chaudhary A, de Alwis DP, Slapak C, Seymour L: Phase I study of the multidrug resistance inhibitor zosuquidar administered in combination with vinorelbine in patients with advanced solid tumours. Cancer Chemother Pharmacol 2005;56:154-160.

19 Marcelletti JF, Multani PS, Lancet JE, Baer MR, Sikic BI: Leukemic blast and natural killer cell P-glycoprotein function and inhibition in a clinical trial of zosuquidar infusion in acute myeloid leukemia. Leuk Res 2009;33:769-774.

20 Morschhauser F, Zinzani PL, Burgess M, Sloots L, Bouafia F, Dumontet C: Phase I/II trial of a P-glycoprotein inhibitor, Zosuquidar.3HCl trihydrochloride (LY335979), given orally in combination with the CHOP regimen in patients with non-Hodgkin's lymphoma. Leuk Lymphoma 2007;48:708-715.

21 Nobili S, Landini I, Giglioni B, Mini E: Pharmacological strategies for overcoming multidrug resistance. Curr Drug Targets 2006;7:861-879.

22 Robak T, Szmigielska-Kaplon A, Pluta A, Grzybowska-Izydorczyk O, Wolska A, Czemerska M, Wierzbowska A: Novel and emerging drugs for acute myeloid leukemia: pharmacology and therapeutic activity. Curr Med Chem 2011;18:638-666.

23 Rubin EH, de Alwis DP, Pouliquen I, Green L, Marder P, Lin Y, Musanti R, Grospe SL, Smith SL, Toppmeyer DL, Much J, Kane M, Chaudhary A, Jordan C, Burgess M, Slapak CA: A phase I trial of a potent P-glycoprotein inhibitor, Zosuquidar.3HCl trihydrochloride (LY335979), administered orally in combination with doxorubicin in patients with advanced malignancies. Clin Cancer Res 2002;8:3710-3717.

24 Ruff P, Vorobiof DA, Jordaan JP, Demetriou GS, Moodley SD, Nosworthy AL, Werner ID, Raats J, Burgess LJ: A randomized, placebo-controlled, double-blind phase 2 study of docetaxel compared to docetaxel plus zosuquidar (LY335979) in women with metastatic or locally recurrent breast cancer who have received one prior chemotherapy regimen. Cancer Chemother Pharmacol 2009;64:763-768.

25 Sandler A, Gordon M, De Alwis DP, Pouliquen I, Green L, Marder P, Chaudhary A, Fife K, Battiato L, Sweeney C, Jordan C, Burgess M, Slapak CA: A Phase I trial of a potent P-glycoprotein inhibitor, zosuquidar trihydrochloride (LY335979), administered intravenously in combination with doxorubicin in patients with advanced malignancy. Clin Cancer Res 2004;10:3265-3272.

26 Tang R, Faussat AM, Perrot JY, Marjanovic Z, Cohen S, Storme T, Morjani H, Legrand O, Marie JP: Zosuquidar restores drug sensitivity in P-glycoprotein expressing acute myeloid leukemia (AML). BMC Cancer 2008;8:51.

27 Bihorel S, Camenisch G, Lemaire M, Scherrmann JM: Modulation of the brain distribution of imatinib and its metabolites in mice by valspodar, zosuquidar and elacridar. Pharm Res 2007;24:1720-1728.

28 Hermann DM, Kilic E, Spudich A, Kramer SD, Wunderli-Allenspach H, Bassetti CL: Role of drug efflux carriers in the healthy and diseased brain. Ann Neurol 2006;60:489-498.

29 Kemper EM, Cleypool C, Boogerd W, Beijnen JH, van Tellingen O: The influence of the P-glycoprotein inhibitor zosuquidar trihydrochloride (LY335979) on the brain penetration of paclitaxel in mice. Cancer Chemother Pharmacol 2004;53:173-178.

30 Infed N, Smits SH, Dittrich T, Braun M, Driessen AJ, Hanekop N, Schmitt L: Analysis of the inhibition potential of zosuquidar derivatives on selected bacterial and fungal $\mathrm{ABC}$ transporters. Mol Membr Biol 2013;30:217-227.

31 Lehne G, De Angelis P, den Boer M, Rugstad HE: Growth inhibition, cytokinesis failure and apoptosis of multidrug-resistant leukemia cells after treatment with P-glycoprotein inhibitory agents. Leukemia 1999;13:768-778.

32 Tang R, Cohen S, Perrot JY, Faussat AM, Zuany-Amorim C, Marjanovic Z, Morjani H, Fava F, Corre E, Legrand O, Marie JP: P-gp activity is a critical resistance factor against AVE9633 and DM4 cytotoxicity in leukaemia cell lines, but not a major mechanism of chemoresistance in cells from acute myeloid leukaemia patients. BMC Cancer 2009;9:199.

33 Lang PA, Kaiser S, Myssina S, Wieder T, Lang F, Huber SM: Role of Ca2+-activated K+ channels in human erythrocyte apoptosis. Am J Physiol Cell Physiol 2003;285:C1553-C1560.

34 Lang E, Qadri SM, Lang F: Killing me softly - suicidal erythrocyte death. Int J Biochem Cell Biol 2012;44:1236-1243. 


\section{Cellular Physiology Cell Physiol Biochem 2015;37:2355-2365 \begin{tabular}{l|l|l} 
and Biochemistry 10.1159/000438589 & $\begin{array}{l}\text { C) } 2015 \text { The Author(s). Published by S. Karger AG, Basel } \\
\text { www.karger.com/cpb }\end{array}$ \\
\hline Published online: December 07, 2015
\end{tabular} \\ Briglia et al.: Zosuquidar-Induced Eryptosis}

35 Abed M, Towhid ST, Mia S, Pakladok T, Alesutan I, Borst O, Gawaz M, Gulbins E, Lang F: Sphingomyelinaseinduced adhesion of eryptotic erythrocytes to endothelial cells. Am J Physiol Cell Physiol 2012;303:C991999.

36 Lau IP, Chen H, Wang J, Ong HC, Leung KC, Ho HP, Kong SK: In vitro effect of CTAB- and PEG-coated gold nanorods on the induction of eryptosis/erythroptosis in human erythrocytes. Nanotoxicology 2012;6:847856.

37 Maellaro E, Leoncini S, Moretti D, Del Bello B, Tanganelli I, De Felice C, Ciccoli L: Erythrocyte caspase-3 activation and oxidative imbalance in erythrocytes and in plasma of type 2 diabetic patients. Acta Diabetol 2013;50:489-495.

38 Bottger E, Multhoff G, Kun JF, Esen M: Plasmodium falciparum-infected erythrocytes induce granzyme B by NK cells through expression of host-Hsp70. PLoS One 2012;7:e33774.

39 Firat U, Kaya S, Cim A, Buyukbayram H, Gokalp O, Dal MS, Tamer MN: Increased caspase-3 immunoreactivity of erythrocytes in STZ diabetic rats. Exp Diabetes Res 2012;2012:316384.

40 Ganesan S, Chaurasiya ND, Sahu R, Walker LA, Tekwani BL: Understanding the mechanisms for metabolism-linked hemolytic toxicity of primaquine against glucose 6-phosphate dehydrogenase deficient human erythrocytes: evaluation of eryptotic pathway. Toxicology 2012;294:54-60.

41 Gao M, Cheung KL, Lau IP, Yu WS, Fung KP, Yu B, Loo JF, Kong SK: Polyphyllin D induces apoptosis in human erythrocytes through $\mathrm{Ca}(2)(+)$ rise and membrane permeabilization. Arch Toxicol 2012;86:741-752.

42 Ghashghaeinia M, Cluitmans JC, Akel A, Dreischer P, Toulany M, Koberle M, Skabytska Y, Saki M, Biedermann T, Duszenko M, Lang F, Wieder T, Bosman GJ: The impact of erythrocyte age on eryptosis. Br J Haematol 2012;157:606-614.

43 Jilani K, Qadri SM, Lang F: Geldanamycin-induced phosphatidylserine translocation in the erythrocyte membrane. Cell Physiol Biochem 2013;32:1600-1609.

44 Polak-Jonkisz D, Purzyc L: Ca Influx versus Efflux during Eryptosis in Uremic Erythrocytes. Blood Purif 2012;34:209-210.

45 Qian EW, Ge DT, Kong SK: Salidroside protects human erythrocytes against hydrogen peroxide-induced apoptosis. J Nat Prod 2012;75:531-537.

46 Vota DM, Maltaneri RE, Wenker SD, Nesse AB, Vittori DC: Differential erythropoietin action upon cells induced to eryptosis by different agents. Cell Biochem Biophys 2013;65:145-157.

47 Weiss E, Cytlak UM, Rees DC, Osei A, Gibson JS: Deoxygenation-induced and $\mathrm{Ca}(2+)$ dependent phosphatidylserine externalisation in red blood cells from normal individuals and sickle cell patients. Cell Calcium 2012;51:51-56.

48 Zappulla D: Environmental stress, erythrocyte dysfunctions, inflammation, and the metabolic syndrome: adaptations to CO2 increases? J Cardiometab Syndr 2008;3:30-34.

49 Zbidah M, Lupescu A, Jilani K, Lang F: Stimulation of suicidal erythrocyte death by fumagillin. Basic Clin Pharmacol Toxicol 2013;112:346-351.

50 Ahmed MS, Langer H, Abed M, Voelkl J, Lang F: The uremic toxin acrolein promotes suicidal erythrocyte death. Kidney Blood Press Res 2013;37:158-167.

51 Ghashghaeinia M, Cluitmans JC, Toulany M, Saki M, Koberle M, Lang E, Dreischer P, Biedermann T, Duszenko M, Lang F, Bosman GJ, Wieder T: Age Sensitivity of NFkappaB Abundance and Programmed Cell Death in Erythrocytes Induced by NFkappaB Inhibitors. Cell Physiol Biochem 2013;32:801-813.

52 Alzoubi K, Honisch S, Abed M, Lang F: Triggering of Suicidal Erythrocyte Death by Penta-O-galloyl-beta-dglucose. Toxins (Basel) 2014;6:54-65.

53 Jilani K, Enkel S, Bissinger R, Almilaji A, Abed M, Lang F: Fluoxetine induced suicidal erythrocyte death. Toxins (Basel) 2013;5:1230-1243.

54 Lupescu A, Bissinger R, Jilani K, Lang F: Triggering of suicidal erythrocyte death by celecoxib. Toxins (Basel) 2013;5:1543-1554.

55 Lupescu A, Jilani K, Zbidah M, Lang F: Patulin-induced suicidal erythrocyte death. Cell Physiol Biochem 2013;32:291-299.

56 Abed M, Zoubi KA, Theurer M, Lang F: Effect of dermaseptin on erythrocytes. Basic Clin Pharmacol Toxicol 2013;113:347-352.

57 Arnold M, Lang E, Modicano P, Bissinger R, Faggio C, Abed M, Lang F: Effect of nitazoxanide on erythrocytes. Basic Clin Pharmacol Toxicol 2014;114:421-426. 


\section{Cellular Physiology Cell Physiol Biochem 2015;37:2355-2365

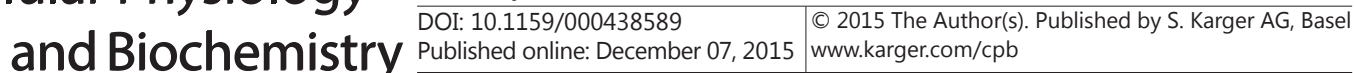 \\ Briglia et al.: Zosuquidar-Induced Eryptosis}

58 Oswald G, Alzoubi K, Abed M, Lang F: Stimulation of suicidal erythrocyte death by ribavirin. Basic Clin Pharmacol Toxicol 2014;114:311-317.

59 Jacobi J, Lang E, Bissinger R, Frauenfeld L, Modicano P, Faggio C, Abed M, Lang F: Stimulation of erythrocyte cell membrane scrambling by mitotane. Cell Physiol Biochem 2014;33:1516-1526.

60 Lupescu A, Bissinger R, Warsi J, Jilani K, Lang F: Stimulation of erythrocyte cell membrane scrambling by gedunin. Cell Physiol Biochem 2014;33:1838-1848.

61 Abed M, Feger M, Alzoubi K, Pakladok T, Frauenfeld L, Geiger C, Towhid ST, Lang F: Sensitization of erythrocytes to suicidal erythrocyte death following water deprivation. Kidney Blood Press Res 2013;37:567-578.

62 Alzoubi K, Calabro S, Bissinger R, Abed M, Faggio C, Lang F: Stimulation of suicidal erythrocyte death by artesunate. Cell Physiol Biochem 2014;34:2232-2244.

63 Arnold M, Bissinger R, Lang F: Mitoxantrone-induced suicidal erythrocyte death. Cell Physiol Biochem 2014;34:1756-1767.

64 Bissinger R, Fischer S, Jilani K, Lang F: Stimulation of erythrocyte death by phloretin. Cell Physiol Biochem 2014;34:2256-2265.

65 Bissinger R, Lupescu A, Zelenak C, Jilani K, Lang F: Stimulation of eryptosis by cryptotanshinone. Cell Physiol Biochem 2014;34:432-442.

66 Bissinger R, Modicano P, Frauenfeld L, Lang E, Jacobi J, Faggio C, Lang F: Estramustine-induced suicidal erythrocyte death. Cell Physiol Biochem 2013;32:1426-1436.

67 Malik A, Bissinger R, Calabro S, Faggio C, Jilani K, Lang F: Aristolochic acid induced suicidal erythrocyte death. Kidney Blood Press Res 2014;39:408-419.

68 Tesoriere L, Attanzio A, Allegra M, Cilla A, Gentile C, Livrea MA: Oxysterol mixture in hypercholesterolemiarelevant proportion causes oxidative stress-dependent eryptosis. Cell Physiol Biochem 2014;34:10751089.

69 Voelkl J, Alzoubi K, Mamar AK, Ahmed MS, Abed M, Lang F: Stimulation of suicidal erythrocyte death by increased extracellular phosphate concentrations. Kidney Blood Press Res 2013;38:42-51.

70 Zhang R, Xiang Y, Ran Q, Deng X, Xiao Y, Xiang L, Li Z: Involvement of calcium, reactive oxygen species, and ATP in hexavalent chromium-induced damage in red blood cells. Cell Physiol Biochem 2014;34:1780-1791.

71 Lupescu A, Bissinger R, Herrmann T, Oswald G, Jilani K, Lang F: Induction of suicidal erythrocyte death by novobiocin. Cell Physiol Biochem 2014;33:670-680.

72 Risso A, Ciana A, Achilli C, Minetti G: Survival and senescence of human young red cells in vitro. Cell Physiol Biochem 2014;34:1038-1049.

73 Zidova Z, Kapralova K, Koralkova P, Mojzikova R, Dolezal D, Divoky V, Horvathova M: DMT1-mutant erythrocytes have shortened life span, accelerated glycolysis and increased oxidative stress. Cell Physiol Biochem 2014;34:2221-2231.

74 Kemper EM, Ouwehand M, Beijnen JH, van Tellingen O: Bioanalysis of zosuquidar trihydrochloride (LY335979) in small volumes of human and murine plasma by ion-pairing reversed-phase highperformance liquid chromatography. J Chromatogr B Analyt Technol Biomed Life Sci 2003;798:63-68.

75 Callies S, de Alwis DP, Mehta A, Burgess M, Aarons L: Population pharmacokinetic model for daunorubicin and daunorubicinol coadministered with zosuquidar.3HCl (LY335979). Cancer Chemother Pharmacol 2004;54:39-48.

76 Qadri SM, Mahmud H, Lang E, Gu S, Bobbala D, Zelenak C, Jilani K, Siegfried A, Foller M, Lang F: Enhanced suicidal erythrocyte death in mice carrying a loss-of-function mutation of the adenomatous polyposis coli gene. J Cell Mol Med 2012;16:1085-1093.

77 Lang E, Gatidis S, Freise NF, Bock H, Kubitz R, Lauermann C, Orth HM, Klindt C, Schuier M, Keitel V, Reich M, Liu G, Schmidt S, Xu HC, Qadri SM, Herebian D, Pandyra AA, Mayatepek E, Gulbins E, Lang F, Haussinger D, Lang KS, Foller M, Lang PA: Conjugated bilirubin triggers anemia by inducing erythrocyte death. Hepatology 2015;61:275-284.

78 Calderon-Salinas JV, Munoz-Reyes EG, Guerrero-Romero JF, Rodriguez-Moran M, Bracho-Riquelme RL, Carrera-Gracia MA, Quintanar-Escorza MA: Eryptosis and oxidative damage in type 2 diabetic mellitus patients with chronic kidney disease. Mol Cell Biochem 2011;357:171-179.

79 Nicolay JP, Schneider J, Niemoeller OM, Artunc F, Portero-Otin M, Haik G, Jr., Thornalley PJ, Schleicher E, Wieder T, Lang F: Stimulation of suicidal erythrocyte death by methylglyoxal. Cell Physiol Biochem 2006;18:223-232. 


\section{Cellular Physiology Cell Physiol Biochem 2015;37:2355-2365

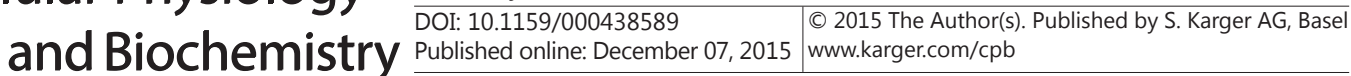 \\ Briglia et al.: Zosuquidar-Induced Eryptosis}

80 Abed M, Artunc F, Alzoubi K, Honisch S, Baumann D, Foller M, Lang F: Suicidal erythrocyte death in endstage renal disease. J Mol Med (Berl) 2014;92:871-879.

81 Lang PA, Beringer O, Nicolay JP, Amon O, Kempe DS, Hermle T, Attanasio P, Akel A, Schafer R, Friedrich B, Risler T, Baur M, Olbricht CJ, Zimmerhackl LB, Zipfel PF, Wieder T, Lang F: Suicidal death of erythrocytes in recurrent hemolytic uremic syndrome. J Mol Med (Berl) 2006;84:378-388.

82 Kempe DS, Akel A, Lang PA, Hermle T, Biswas R, Muresanu J, Friedrich B, Dreischer P, Wolz C, Schumacher U, Peschel A, Gotz F, Doring G, Wieder T, Gulbins E, Lang F: Suicidal erythrocyte death in sepsis. J Mol Med (Berl) 2007;85:273-281.

83 Foller M, Braun M, Qadri SM, Lang E, Mahmud H, Lang F: Temperature sensitivity of suicidal erythrocyte death. Eur J Clin Invest 2010;40:534-540.

84 Felder KM, Hoelzle K, Ritzmann M, Kilchling T, Schiele D, Heinritzi K, Groebel K, Hoelzle LE: Hemotrophic mycoplasmas induce programmed cell death in red blood cells. Cell Physiol Biochem 2011;27:557-564.

85 Lang PA, Kasinathan RS, Brand VB, Duranton C, Lang C, Koka S, Shumilina E, Kempe DS, Tanneur V, Akel A, Lang KS, Foller M, Kun JF, Kremsner PG, Wesselborg S, Laufer S, Clemen CS, Herr C, Noegel AA, Wieder T, Gulbins E, Lang F, Huber SM: Accelerated clearance of Plasmodium-infected erythrocytes in sickle cell trait and annexin-A7 deficiency. Cell Physiol Biochem 2009;24:415-428.

86 Kempe DS, Lang PA, Duranton C, Akel A, Lang KS, Huber SM, Wieder T, Lang F: Enhanced programmed cell death of iron-deficient erythrocytes. FASEB J 2006;20:368-370.

87 Lang KS, Roll B, Myssina S, Schittenhelm M, Scheel-Walter HG, Kanz L, Fritz J, Lang F, Huber SM, Wieder T: Enhanced erythrocyte apoptosis in sickle cell anemia, thalassemia and glucose-6-phosphate dehydrogenase deficiency. Cell Physiol Biochem 2002;12:365-372.

88 Lang PA, Schenck M, Nicolay JP, Becker JU, Kempe DS, Lupescu A, Koka S, Eisele K, Klarl BA, Rubben H, Schmid KW, Mann K, Hildenbrand S, Hefter H, Huber SM, Wieder T, Erhardt A, Haussinger D, Gulbins E, Lang F: Liver cell death and anemia in Wilson disease involve acid sphingomyelinase and ceramide. Nat Med 2007;13:164-170.

89 Borst O, Abed M, Alesutan I, Towhid ST, Qadri SM, Foller M, Gawaz M, Lang F: Dynamic adhesion of eryptotic erythrocytes to endothelial cells via CXCL16/SR-PSOX. Am J Physiol Cell Physiol 2012;302:C644-C651.

90 Andrews DA, Low PS: Role of red blood cells in thrombosis. Curr Opin Hematol 1999;6:76-82.

91 Chung SM, Bae ON, Lim KM, Noh JY, Lee MY, Jung YS, Chung JH: Lysophosphatidic acid induces thrombogenic activity through phosphatidylserine exposure and procoagulant microvesicle generation in human erythrocytes. Arterioscler Thromb Vasc Biol 2007;27:414-421.

92 Zwaal RF, Comfurius P, Bevers EM: Surface exposure of phosphatidylserine in pathological cells. Cell Mol Life Sci 2005;62:971-988.

93 Closse C, Dachary-Prigent J, Boisseau MR: Phosphatidylserine-related adhesion of human erythrocytes to vascular endothelium. Br J Haematol 1999;107:300-302.

94 Gallagher PG, Chang SH, Rettig MP, Neely JE, Hillery CA, Smith BD, Low PS: Altered erythrocyte endothelial adherence and membrane phospholipid asymmetry in hereditary hydrocytosis. Blood 2003;101:46254627.

95 Pandolfi A, Di Pietro N, Sirolli V, Giardinelli A, Di Silvestre S, Amoroso L, Di Tomo P, Capani F, Consoli A, Bonomini M: Mechanisms of uremic erythrocyte-induced adhesion of human monocytes to cultured endothelial cells. J Cell Physiol 2007;213:699-709.

96 Wood BL, Gibson DF, Tait JF: Increased erythrocyte phosphatidylserine exposure in sickle cell disease: flowcytometric measurement and clinical associations. Blood 1996;88:1873-1880. 